Society and the Society of Friends, but expenditure on outlay is necessarily restricted when the land may (after three months notice) be sold to a speculative builder. Lady Allen of Hurtwood discusses this problem in a booklet entitled "How Allotments could be made an Amenity Asset to the Community". Constructive suggestions for the development of the allotment garden as an outdoor social centre are made, stress being laid on the necessity for wellconsidered planning of the land from the start, if possible in conjunction with other forms of social activity. An illustration is given of a suitable lay-out designed by the author herself, and sketches for a community centre building and hut units by William Tatton Brown are also included. The booklet (price 4d. post paid) may be obtained from The Housing Centre, 13 Suffolk Street, London, S.W.1.

\section{Professional Workers in the Ukraine}

Figures have recently been issued by the Soviet Union Year Book Press Service relating to the increase in the number of Soviet professional workers in the Ukraine. In 1914, the territory now constituting Soviet Ukraine had 44,083 teachers; at the beginning of the school year 1936-37 the number had risen to 150,000 . The number of medical men in 1913 was 5,192 , in 1936 it was 19,266 . The number of secondary medical staff in 1913 was 8,357 and in 193640,243 . In 1934 there were 83,390 engineers and technical experts employed in the Ukraine; in 1936 the number had increased to 116,600 . The number of agronomists employed by the Commissariat of Agriculture in the Ukraine three years ago was 8,200 ; in January 1936 it was 12,346 .

\section{The Public Health Act, 1936}

THE Ministry of Health has issued a circular to local authorities reminding them that the above Act, which passed into law in July last, comes into operation on October 1, 1937 (Circular No. 1576. H.M. Stationery Office). Attention is directed to some of the more important changes introduced in the new Act and to matters which call for early consideration. This Act consolidates in some 350 sections the provisions of more than six hundred sections contained in some sixty existing Acts.

\section{Gift to the Royal Aeronautical Society}

Mr. C. R. FAIRfy, past president of the Royal Aeronautical Society, and Mr. F. Handley Page, vicepresident, have jointly agreed to give $£ 750$ a year for seven years to the Society. The object of this gift is to enable the Society to carry out as fully as possible its main object, "the general advancement of aeronautical science and engineering", and to enable it to be placed on a self-supporting basis. The intention is that the Society should become completely independent of donations from outside bodies, so that it may be free to express opinions upon aeronautical research and engineering when necessary, and can encourage the dissemination of papers, etc., on all matters pertaining to aeronautical research and engineering.

\section{Announcements}

The Right Hon. the Viscount Falmouth has been appointed a member of the Advisory Council to the Committee of the Privy Council for Scientific and Industrial Research. Prof, A. C. G. Egerton has retired from the Council on completion of his term of office.

Sir John Parsons, the new president of the Royal Society of Medicine, has recently returned from the United States, where he was awarded the Iucien Howe Medal of the American Ophthalmological Society.

Prof. Nocht, the founder and former director of the Institute of Marine and Tropical Medicine at Hamburg, has been awarded the Gold Medal of the University in recognition of his great services to the University in the domain of scientific work overseas.

Erratum. In Nature of November 21, p. 875, paragraph entitled "Grassland of Great Britain", line 16, for " $150 \mathrm{ft}$. contour" read "1500 ft. contour".

Appurcatrons are invited for the following appointments, on or before the dates mentioned :

Two male pharmacists in the Royal Naval Hospitals-The Medical Director-General of the Navy, Admiralty, S.W.1 (November 28).

A mechanical and automobile engineer in the Yorkshire Traffic Area office at Leeds-The Establishment Secretary, Ministry of Transport, 6 Whitehall Gardens, S.W.1 (November 30).

A chief agricultural officer to the Salop County Council--The Clerk of the County Council, Shirehall, Shrewsbury (December 5).

An assistant physicist in the Radiotherapy Department, Royal Infirmary, Bradford-The SecretarySuperintendent (December 7).

Assistants (Grades II and III) in metallurgy in Admiralty Dockyard Establishments-The Secretary of the Admiralty (C.E. Branch), Whitehall, London, S.W.1 (quote C.E. 7180/36) (December 12).

A lecturer in mining surveying and economics in the Bulawayo Technical School-The Official Secretary, Office of the High Commissioner for Southern Rhodesia, Rhodesia House, 429 Strand, London, W.C.2 (December 12).

An assistant director, with a knowledge of textiles, of the Testing House and Laboratory of the Manchester Chamber of Commerce-The Director, Testing House, Royal Exchange, Manchester (December 15).

A taxidermist and an articulator in the National Museum, Melbourne-The Agent-General for Victoria, Victoria House, Melbourne Place, Strand, W.C.2 (January 4).

A professor of mechanical engineering in the Benares Hindu University-The Pro-Vice-Chancellor, Benares Hindu University, Benares, India (January 15).

A county agricultural organizer in Leicestershire --The Director of Education, Gray Friars, Leicester.

A lecturer in mathematics (woman) in the Avery Hill Training College, Eltham, S.E.9-The Principal. 